continually delivered a service of an exeptionally high standard despite the varying working circumstances (tents and makeshift accommodation, hospital ships and trains, and modern ambulance aircraft).

Although reasonably well illustrated, the book is not furnished with maps. In any history of this kind, maps are essential: they not only position geographical place names which may be relatively obscure, but also give the reader instant information with regard to distance and physical features (such as mountains, rivers and seas).

From a technical point of view, Military Nursing might have needed a little extra attention. The absence of a title on the spine lends anonymity and allows the book to "get lost" when placed on a shelf with numerous other volumes. There is, furthermore, no half-title page and an unfortunate number of spelling mistakes. A blurb, on the back cover, might also have been included to present either (or both) a summary of the contents or an introduction of the writers.

Military Nursing is essentially a chronicle with little to no appreciation made of the material and no discussion of afflictions and diseases suffered by South African troops in various theatres at different times. This material, now available to researchers, might have lent depth, colour and scope. Military Nursing, nonetheless, is the first step in the closing of a yawning gap in our military history and will provide a foundation for further research.

Major I.J.van der Waag, Documentation Service Directorate, Private Bag X289, Pretoria 0001.

\section{POTCHEFSTROOM KOMMANDO; HULLE WAS ALTYD DAAR, 1838-1990}

\author{
V.L. Hamilton-Attwell \\ 1995. \\ $155 \mathrm{pp}$ \\ prys onbekend
}

Hierdie publikasie verskyn op ' $n$ stadium wat die kommando-stelsel weereens onder die soeklig is. In hierdie verband word daar verwys na die onlangse uitspraak van die ANC se parlementêre koukus, waarin die organisasie ten gunste is van die afskaffing van die kommando-stelsel, aangesien dit kwansuis regsgesindes akkommodeer ('Don't dismiss commando - officer', Pretoria News 12 September 1995). Daar moet egter onthou word dat die kommando's ' $n$ groot bydra gelewer het in die handhawing van vrede tydens die verkiesings in April 1994. Hierbenewens is die kommando's ook aktief betrokke om die SAPD by te staan in die bekamping van misdaad veral in die plattelandse gebiede. Die waarde van die kommando's moet dus nie onderskat word nie.

Soos wat die skrywer in die inleiding noem, is hierdie boek gerig op diegene wat lid van die Kommando is of was en wie se lewe deur die Kommando geraak is. Die boek behandel die uitstaande gebeurtenisse wat die Potchefstroom Kommando se geskiedenis oor ' $n$ tydperk van 150 jaar beïnvloed het. Alhoewel die boek fokus op die Potchefstroom Kommando, dek die bespreking veel meer as net die wel en weë van hierdie kommando. Daar word byvoorbeeld gekyk na die ontwikkeling van die kommandostelsel tot die vorm wat dit huidiglik aanneem : dit behels die behandeling van onder meer die Verdedigingsskietverenigings en die Skietkommandostelsel (hoofstukke ses en sewe).

Die outeur voer die ontstaan van die kommando's terug tot sover as die koms van Jan van Riebeeck in 1652. Die kommando-stelsel is gebore uit die behoefte van die koloniste om ' $n$ verdedigingstelsel op die been te bring om hulself te beskerm teen invalle van die omliggende inboorlingstamme. Aandag word ook gegee aan die ontwikkeling van die rangstelsel en struktuur van die kommando's. Die herkoms van sekere range soos Kommandant en Veldkornet word kortliks bespreek en verskaf interessante leesstof.

Die boek het ' $n$ persoonlike inslag deurdat die aandag gevestig word op persone wat ' $n$ besondere bydra gelewer het tot die Kommando, die medaljes wat deur lede van die Kommando ontvang is asook op die skietprestasies van lede tydens skietkompetisies (hoofstukke vier, vyf en sewe). Hier moet ook genoem word dat die skrywer vir 'n lang tydperk verbonde was aan die Kommando en ook bevelvoerder van die eenheid was.

Die inhoud van die boek word chronologies aangebied. Die invloed van politieke gebeure en die veranderinge in die kommando-stelsel op die Potchefstroom Kommando word logies aangebied in fases, naamlik fase een (1902-1948), fase twee (1948-1979) en fase drie (1980-1990).

Die teks word ondersteun deur talle foto's en kaarte wat onontbeerlik is om die visuele beeld van die eenheid tuis te bring. Die publikasie het ongelukkig nie ' $n$ buiteblad wat die oog vang nie, maar die feit dat dit ' $n$ hardebandomslag het, beteken dat die publikasie ' $n$ lang raklewe sal hê. Die boek word uitgegee deur Lt kol V.L. Hamilton-Attwell, Posbus 21136, Noordburg 2522.

Wat die boek as naslaanwerk nuttig maak is die gebruik van voetnotas wat dit vir die navorser, wat 
dalk wyer oor 'n sekere aspek van die boek sou wou lees, makliker maak om die inligting op te spoor. Die literatuurlys getuig van die groot verskeidenheid bronne wat geraadpleeg is, byvoorbeeld tydskrifte, koerante, argivale bronne en persoonlike onderhoude.

Weinig kommando's of selfs hoofkwartiereen- eenhede beskik oor so 'n omvattende geskrewe geskiedenis. Die hoop word hiermee uitgespreek dat hierdie publikasie, van hoogstaande gehalte, ander eenhede sal aanspoor om dieselfde te doen.

A. van der Westhuizen, Direktoraat Dokumentasiediens, Privaatsak X289, Pretoria 0001. 